Jurnal Homepage: http://journal2.um.ac.id/index.php/jaa (p-ISSN: 2087-9695; e-ISSN: 2580-1015)

\title{
Reaksi pasar modal terhadap kebijakan buyback saham tanpa persetujuan RUPS
}

\author{
Serly Calista Asiali ${ }^{1}$, Bety Nur Achadiyah ${ }^{1}$ \\ ${ }^{1}$ Universitas Negeri Malang, Jl. Semarang No. 5 Malang, Indonesia
}

\section{Diterima: \\ 15 Mei 2021 \\ Direvisi: \\ 1 Juli 2021 \\ Disetujui: \\ 4 Juli 2021}

Korespondensi:

Serly Calista Asiali

serly.calista.1704226@

students.um.ac.id

\section{DOI:}

http://dx.doi.org/10.17977/ um004v8i22021p149

\begin{abstract}
This study aims to investigate the market's reaction to the announcement of a stock buyback policy without the authorization of Annual General Meeting (AGM), as evidenced by abnormal returns within the window periods. A paired sample t-test was applied to compare the abnormal return before and after the announcement of the share buyback by Otoritas Jasa Keuangan $(\mathrm{OJK})$ policy. The results show that there are no significant difference in abnormal return before and after the announcement. However, the market still responds to this information as can be observed by the difference in the average abnormal return. It demonstrates that the announcement of the stock buyback scheme without AGM authorization still provides information.
\end{abstract}

Keywords: OJK Policy; Buyback; Abnormal Return; Annual General Meeting

\begin{abstract}
Abstrak
Penelitian ini bertujuan untuk melihat dampak pengumuman buyback saham tanpa persetujuan Rapat Umum Pemegang Saham (RUPS) di pasar modal yang ditunjukkan oleh keberadaan abnormal return selama window period. Uji paired sample t-test digunakan untuk membandingkan abnormal return sebelum dan sesudah peristiwa diumumkannya kebijakan buyback saham oleh Otoritas Jasa keuangan $(\mathrm{OJK})$. Hasil uji tersebut menunjukkan bahwa tidak terdapat perbedaan abnormal return yang signifikan sebelum dan sesudah pengumuman kebijakan buyback saham tanpa persetujuan RUPS. Namun demikian, pasar tetap merespon informasi tersebut dengan adanya perbedaan rata-rata abnormal return. Hal ini mengindikasikan bahwa pengumuman buyback saham tanpa persetujuan RUPS memiliki kandungan informasi.

Kata kunci: Kebijakan OJK; Buyback, Abnormal Return, Rapat Umum Pemegang Saham
\end{abstract}

\section{PENDAHULUAN}

Salah satu kebijakan yang diberlakukan Otoritas Jasa Keuangan (OJK) untuk menghadapi masa pandemi adalah pelaksanaan pembelian saham kembali (buyback saham) yang diterbitkan oleh emiten atau perusahan publik. Kebijakan ini diterbitkan tanggal 9 Maret 2020 melalui Surat Edaran OJK Nomor 3/SEOJK.04/2020. Kebijakan ini merelaksasi dua hal dalam pelaksanaan buyback saham, yaitu pembelian kembali dapat dilakukan tanpa memperoleh persetujuan RUPS, serta jumlah saham yang dapat dibeli kembali dapat lebih dari 10\% dengan batas maksimum 20\% dari modal disetor, dengan syarat saham yang beredar minimal sebesar 7,5\% modal disetor. Kebijakan ini diberlakukan akibat adanya tekanan pada kondisi perdagangan saham di BEI dari awal tahun 2020 hingga 9 Maret 2020 yang menyebabkan penurunan IHSG sampai angka 18,46\%. Kebijakan buyback saham tanpa persetujuan RUPS merupakan salah satu upaya OJK untuk memberikan stimulus perekonomian dan pengurangan dampak pasar.

Penelitian-penelitian terdahulu telah menggunakan parameter yang umum digunakan dalam menguji reaksi pasar saham yaitu abnormal return. Peristiwa yang dijadikan acuan dalam penelitian terdahulu adalah peristiwa serupa dan memiliki keberlanjutan dari penelitian sebelumnya. Hal ini menandakan kurang adanya perbedaan spesifik diantara penelitian-penelitian yang ada. Berdasarkan penelitian terdahulu, penelitian ini memilih peristiwa kebijakan buyback saham tanpa persetujuan RUPS yang merupakan peristiwa yang baru saja terjadi dan diduga dapat memengaruhi reaksi pasar modal. Kebijakan ini diterbitkan sebagai dampak dari pandemi COVID-19 yang memiliki perbedaan 
dimana buyback dapat dilakukan oleh emiten tanpa persetujuan RUPS. Hal ini merupakan perubahan dari pasal 37 UU RI No. 40 Tahun 2007 tentang Perseroan Terbatas (PT) mengenai pembelian kembali saham atau pengalihannya lebih lanjut hanya boleh dilakukan berdasarkan persetujuan RUPS. Selain itu, syarat pembelian kembali saham pada kebijakan ini boleh melebihi 10\% dari jumlah modal yang ditempatkan, berbeda dengan ketentuan yang ditetapkan pada UU PT. Perbedaan dengan penelitian serupa yang telah dilakukan oleh Saragih (2015) menjadi alasan penelitian ini perlu dilakukan.

Teori yang menjadi dasar penelitian ini adalah teori efisiensi pasar. Teori ini menjelaskan hubungan antara perilaku harga/return saham yang diperdagangkan dengan peristiwa publikasi informasi baru atau kejadian-kejadian yang dapat memengaruhi persepsi dan keyakinan pelaku pasar (Beaver (1998) dalam Lako (2008)). Teori efisiensi pasar dipilih karena fokus penelitian terletak pada reaksi pasar modal terhadap peristiwa penerbitan Surat Edaran OJK Nomor 3/SEOJK.04/2020, bukan kepada angka-angka yang disajikan perusahaan untuk memberi sinyal kepada investor. Adanya kebijakan OJK buyback saham tanpa persetujuan RUPS ini merupakan salah satu informasi publik yang dapat memengaruhi keputusan stakeholders termasuk investor. Publikasi kebijakan ini dapat mempengaruhi investor untuk berinvestasi atau menghentikan investasi pada suatu perusahaan. Tindakan investor tersebut menyebabkan reaksi pasar modal yang dapat diukur dengan indikator abnormal return, dimana reaksi ini sesuai dengan teori efisiensi pasar.

Reaksi pasar saham terhadap suatu peristiwa telah menjadi topik penelitian yang umum. Penelitian terhadap peristiwa ekonomi telah dilakukan oleh Wibowo \& Sukmaningrum (2020), Yulita (2017), dan Saragih (2015) dengan indikator average abnormal return dan trading volume activity dan menemukan adanya abnormal return dan peningkatan trading volume activity. Namun, pada penelitian Sanjiwani \& Jati (2017) perbedaan yang signifikan tidak tampak pada hasil. Penelitian oleh Satryo \& Wijayanto (2019) yang menggunakan tiga indikator menemukan bahwa hanya trading volume activity yang berbeda. Hasil penelitian Rante, Falah, \& Pangayow (2019) juga tidak menemukan perbedaan abnormal return yang signifikan, tetapi reaksi pasar terlihat dari trading volume activity. Selain peristiwa ekonomi, reaksi pasar juga muncul akibat adanya peristiwa politik. Penelitian oleh Wibowo (2017) menunjukkan adanya abnormal return yang positif. Saraswati \& Mustanda (2018) juga menemukan adanya perbedaan abnormal return. Putra \& Putri (2018) juga menemukan perbendaan rata- rata abnormal return dan trading volume activity.

Isa, Ghani, \& Lee (2011) dan Pirgaip (2021) mendapatkan hasil yang positif. Pradhan \& Kasilingam (2018)market situation, lack of investment opportunity and so on. In fact, it may affect the share price movement and company's performance. In the last couple of years, there is a significant increase of funds offered for buyback in the Indian capital market. Therefore, the study attempts to find out its impact on shareholders' wealth. To know this impact, buyback announcement are analysed industry-wise using companies of BSE 500 index. The samples are selected based on prescribed criteria made by the researcher which are exclusively related to the number of times buyback programmes are announced by companies under a particular industry. The study analyses the share price movement of sampled companies for 30 days before and 30 days after the announcement. The market adjusted model is used to calculate the abnormal returns (AR menggunakan indikator abnormal return dan mendapatkan hasil bahwa pembelian kembali hanya mempengaruhi harga saham beberapa sektor saja. Penelitian oleh Smith (2016) serta Gupta \& Wagner (2018)we analyzed the magnitude and determinants of the share price reaction on announcement. Our results indicate that buyback announcements in Europe lead on average to a significantly positive abnormal return of $0.92 \%$ on announcement day, however, decreasing in firm size and announcement frequency. Additionally, our findings show that the market does not particularly greet the distribution of excess cash to shareholders, but rather when companies take advantage of undervalued stock as marketto-book values are inversely related to announcement returns. Looking at the companies' leverage ratios, the motive of capital structure optimization cannot be supported by the empirical findings. Lastly, with respect to managerial market timing ability we could not observe that buybacks are following a period of share price underperformance, concluding that managers are not able to time the implementation of buyback programs (Gupta and Wagner, 2018 menemukan abnormal return yang signifikan dan positif. Sivashanmugam \& Sowmya (2019) mendapatkan hasil bahwa secara kumulatif, abnormal return bernilai lebih rendah daripada hari pengumuman, dan abnormal return bernilai positif signifikan pada periode sebelum pengumuman. Niu (2015) juga menemukan bahwa rerata positif abnormal return pada waktu pengumuman pembelian kembali saham di masa normal atau saat krisis, dan meningkat secara signifikan ketika krisis. Zhang et al. (2016) mendapatkan abnormal return yang positif signifikan dan peningkatan volume perdagangan pada tanggal peristiwa terjadi. Penelitian oleh Jin \& Kim (2018) menemukan abnormal return yang positif pada tiga sektor, tetapi Singh et al. (2020) mendapatkan abnormal return yang negatif signifikan, serta penurunan cumulative average 
abnormal return setelah hari ke-43. Khanthavit (2020) menyatakan bahwa pandemi menyebabkan reaksi pasar yang negatif signifikan. Hasil penelitian yang beragam disebabkan oleh peristiwa yang diteliti dan dampak yang diperoleh dari peristiwa tersebut. Pada penelitian ini, peristiwa penerbitan kebijakan OJK buyback saham tanpa persetujuan RUPS menjadi variabel yang diuji pengaruhnya terhadap pasar modal dengan menggunakan indikator abnormal return. Hipotesis yang dirumuskan adalah sebagai berikut:

$\mathrm{H}_{\mathrm{A}}$ : Terdapat perbedaan abnormal return sebelum dan sesudah peristiwa penerbitan kebijakan OJK buyback saham tanpa persetujuan RUPS pada masa pandemi.

\section{METODE}

Penelitian ini termasuk dalam penelitian studi peristiwa (event study) yang melihat dampak dari pengumuman yang dikeluarkan oleh OJK tentang buyback saham tanpa persetujuan RUPS terhadap perubahan abnormal return (Hartono et al., 2019). Periode peristiwa dalam penelitian ini adalah 21 hari. Penentuan periode ini sesuai dengan penelitian terdahulu oleh Yulita (2017), Sivashanmugam \& Sowmya (2019), serta Wibowo \& Sukmaningrum (2020). Periode tersebut diharapkan mewakili reaksi pasar modal (abnormal return) terhadap peristiwa yang diteliti karena dalam periode tersebut telah terdapat sejumlah perusahaan yang mengumumkan keterbukaan informasi akan melakukan buyback. Selain itu, periode peristiwa yang tidak terlalu lama bertujuan untuk menghindari bias atau tertumpuknya informasi atas satu peristiwa dengan peristiwa lainnya. Periode tersebut terbagi menjadi tiga periode yaitu 10 hari sebelum pengumuman kebijakan, satu hari pada saat pengumuman kebijakan, dan 10 hari setelah pengumuman kebijakan.

Setelah peneliti menentukan periode peristiwa, data yang akan digunakan untuk mengukur abnormal return dikumpulkan. Data ini berupa data skunder yang diperoleh melalui website Bursa Efek Indonesia (www.idx.co.id). Kebijakan OJK buybacksaham tanpa persetujuan RUPS diberlakukan mulai 9 Maret 2020 hingga 29 September 2020, tetapi periode pengamatan yang diambil dalam penelitian ini adalah 21 hari. Sampel dalam penelitian ini adalah 58 perusahaan yang telah melakukan pembelian saham kembali setelah penetapan kebijakan OJK serta bebas dari confounding effect.

Data yang didapat kemudian diolah untuk mendapatkan abnormal return pada periode peristiwa. Abnormal return diperoleh dari perhitungan actual return, expected return kemudian lanjut dengan abnormal return (Suganda, 2018). Selanjutnya, uji hioptesis dilakukan dengan uji beda paired samples t-test untuk mengetahui apakah memiliki perbedaan rata-rata yang secara nyata atau tidak (Hidayat \& Istiadah, 2011; Saragih, 2015). Perbedaan yang dimaksud dapat diketahui dari nilai signifikansinya (2-tailed) dengan batas sigifikansi 0,05.

\section{HASIL DAN PEMBAHASAN}

Gambar 1 menunjukkan pengamatan yang meliputi pergerakan return saham, Indeks Harga Saham Gabungan (IHSG), serta grafik rata-rata abnormal return pada periode peristiwa yang diteliti, meliputi 10 hari sebelum peristiwa, 1 hari saat peristiwa terjadi, dan 10 hari setelah peristiwa. Gambar 1 menunjukkan bahwa fluktuasi kurang terlihat pada keseluruhan return sampel. Return yang paling terlihat perbedaannya yakni pada return PT Steel Pipe Industry of Indonesia Tbk. (ISSP) di mana saham ini yang memiliki return tertinggi dan terendah. Return tertinggi diantara semua sampel yaitu sebesar 1,296296 pada hari kedua setelah peristiwa terjadi. Sementara return terendah terlihat pada hari ketiga setelah peristiwa yakni sebesar $-0,622581$. Hal ini menunjukkan bahwa return saham ISSP lebih merespon peristiwa kebijakan OJK buyback saham tanpa RUPS dibandingkan dengan perusahaan lainnya.

Gambar 2 menunjukkan perubahan nilai Indeks Harga Saham Gabungan (IHSG) yang cukup fluktuatif sebelum peristiwa terjadi. Peningkatan IHSG terbesar terlihat pada hari ke-4 sebelum peristiwa terjadi, yaitu sebesar 157,382. Penurunan IHSG terbesar terletak pada saat terjadinya peristiwa yaitu sebesar -361,731. Setelah perisiwa terjadi, IHSG mengalami penurunan hingga nilai Rp 3,989,52 pada hari ke-10 setelah peristiwa terjadi.

Gambar 3 menunjukkan pergerakan rata-rata abnormal return selama 21 hari periode peristiwa. Rata-rata abnormal return cukup berfluktuasi pada 10 hari sebelum peristiwa terjadi. Perubahan paling signifikan pada 10 hari sebelum pengumuman terletak antara hari ke- 9 dan hari ke- 8 sebelum peristiwa, yaitu penurunan sebesar 0,01421. Namun, rata-rata abnormal return pada periode setelah peristiwa lebih fluktuatif dibandingkan dengan sebelum peristiwa terjadi. Hal itu tampak pada penurunan rata-rata abnormal return yang cukup signifikan antara hari ke-2 dan hari ke-3 setelah peristiwa terjadi sebesar 0,02311. Secara keseluruhan, rata-rata abnormal return pada hari ke-3 setelah peristiwa memiliki nilai paling rendah yaitu sebesar $-0,01847$, sementara nilai tertinggi terdapat pada hari terakhir periode peristiwa sebesar 0,00847. 


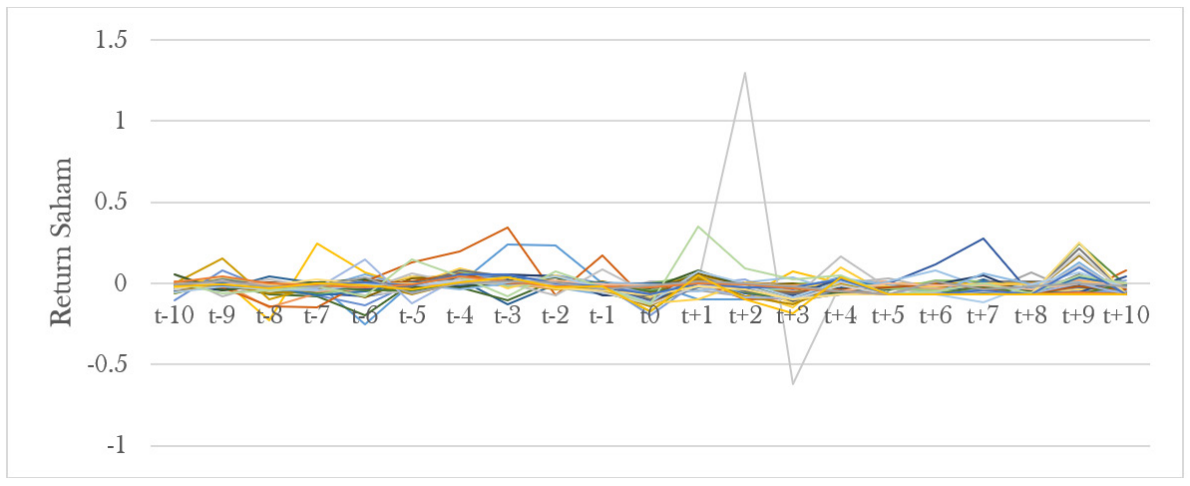

Gambar 1. Pergerakan return saham para periode peristiwa

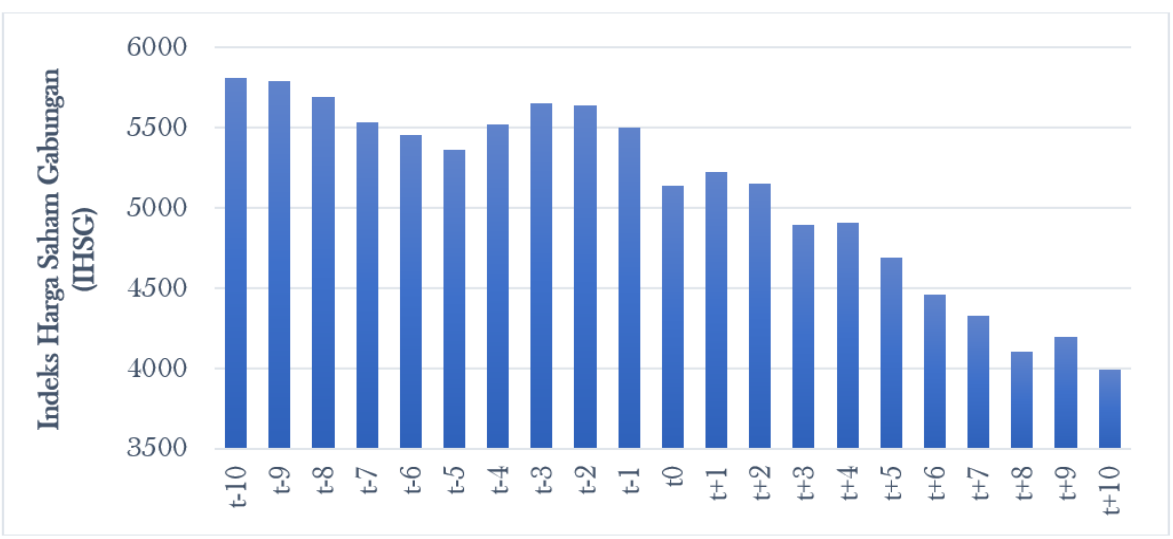

Gambar 2. Pergerakan IHSG pada periode peristiwa

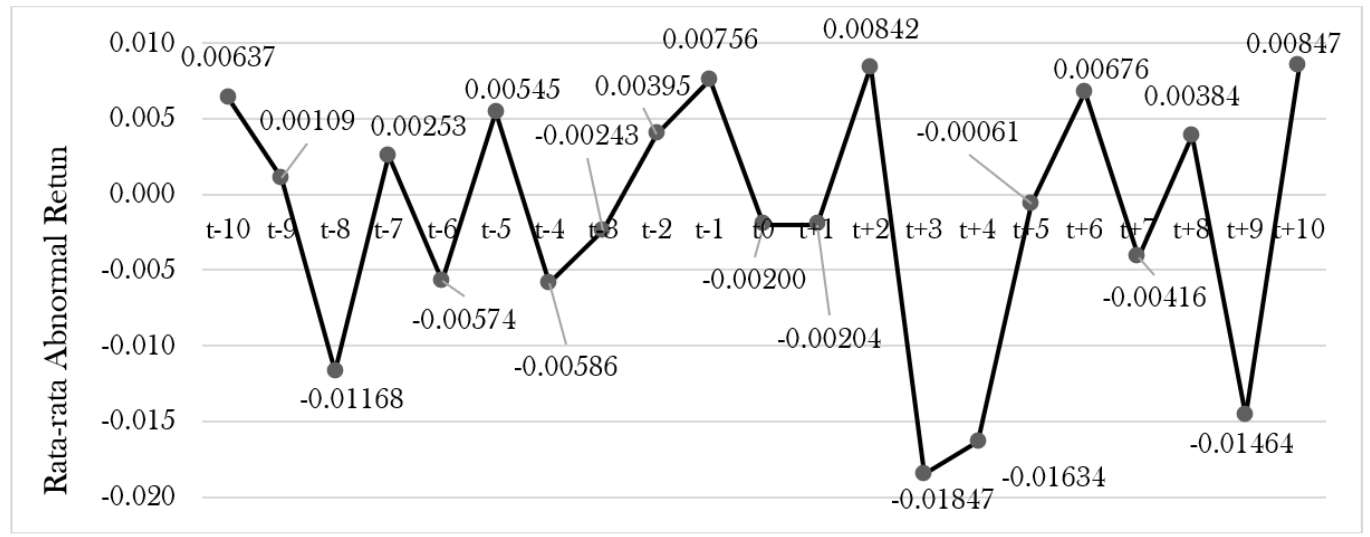

Gambar 3. Pergerakan abnormal return para periode peristiwa

Uji normalitas digunakan dalam penelitian ini sebagai prasyarat untuk uji beda. Hasil uji Kolmogorov-Smirnov Z menunjukkan nilai signifikansi abnormal return sebesar 0,173, sehingga data dalam penelitian ini berdistribusi normal. Hasil uji paired sample t-testmenunjukkan nilai signifikansi sebesar 0,355 sehingga hipotesis ditolak. Hal ini menunjukkan tidak ada perbedaan antara abnormal return sebelum dan sesudah peristiwa peluncuran kebijakan OJK buyback saham tanpa RUPS. Berdasarkan hasil tersebut, dapat disimpulkan bahwa tidak terdapat reaksi pasar modal (abnormal return) terhadap peristiwa kebijakan OJK buyback saham tanpa RUPS.

Hasil penelitian ini menandakan tidak adanya perbedaan abnormal return yang signifikan sebelum dan sesudah peristiwa peluncuran kebijakan OJK. Meskipun tidak signifikan, pasar merespons informasi yang terlihat dari adanya perbedaan rata-rata abnormal return. Adapun perbedaan rata-rata abnormal return sebelum dan sesudah peristiwa yakni dari sebesar 0,000123 sebelum peristiwa hingga sebesar $-0,002877$ setelah peristiwa terjadi. Keberlakuan teori efisiensi pasar menurut Beaver, (1998) dalam Lako (2008) yang menjadi dasar penelitian ini tidak terbukti karena 
tidak ditemukannya hubungan antara informasi penerbitan kebijakan OJK dengan harga saham di pasar modal. Penelitian ini mendapatkan hasil yang sejalan dengan penelitian oleh Rante, Falah, \& Pangayow (2019) yang menemukan bahwa abnormal return sebelum dan sesudah pengumuman paket kebijakan ekonomi XVI tidak memperlihatkan adanya perbedaan yang signifikan. Penelitian terdahulu yang mendapatkan hasil serupa yaitu Satryo \& Wijayanto (2019) yang menyatakan pada sebelum dan sesudah peristiwa perang dagang, average abnormal return dan average security return variability tidak memperlihatkan perbedaan, meskipun tampak perbedaan pada trading volume activity. Pada peristiwa tax amnesty, Sanjiwani \& Jati (2017) juga tidak menemukan perbedaan yang signifikan dari rata-rata abnormal return sebelum dan sesudah kebijakan. Hasil yang berbeda didapatkan oleh Saragih (2015), Wibowo (2017), dan Wibowo \& Sukmaningrum (2020) dimana abnormal return sebelum dan sesudah peristiwa memiliki perbedaan.

Penelitian ini berfokus pada peristiwa penerbitan kebijakan OJK buyback saham tanpa persetujuan RUPS dengan jumlah nominal saham yang dapat dibeli lebih besar daripada buyback pada umumnya, yakni dapat lebih dari 10\% dengan maksimal 20\% saham beredar. Penelitian ini berbeda dengan penelitian Saragih (2015) yang berfokus pada pengumuman buyback atau pembelian kembali saham. Adanya perbedaan peristiwa dan syarat dalam melakukan pembelian kembali memungkinkan munculnya reaksi pasar modal. Penerbitan kebijakan merupakan salah satu infomasi yang menjadi bahan pertimbangan investor untuk mengambil keputusan investasi karena informasi tersebut bersifat publik. Reaksi tersebut terlihat pada perbedaan rata-rata abnormal return sebelum dan sesudah peristiwa walaupun tidak signifikan. Hal ini menunjukkan bahwa informasi penerbitan kebijakan OJK merupakan informasi yang tidak cukup kuat untuk memengaruhi pasar modal. Selain itu, tidak adanya perbedaan rata-rata abnormal return yang signifikan dapat disebabkan oleh kurangnya penyampaian informasi kepada investor, serta kurangnya pemahaman investor mengenai manfaat dari kebijakan OJK buyback saham tanpa persetujuan RUPS bagi perusahan dan investor di masa yang akan datang.

Reaksi pasar modal terhadap peluncuran kebijakan OJK tampak kurang responsif pada periode peristiwa yang dipilih. Rata-rata abnormal return menunjukkan adanya penurunan yang signifikan pada hari ketiga setelah peristiwa. Hal ini menandakan bahwa terdapat keterlambatan penerimaan informasi mengenai peristiwa kebijakan OJK buyback saham tanpa persetujuan RUPS. Selain itu, pergerakan rata-rata abnormal return yang terlambat dapat disebabkan oleh jeda waktu perusahaan memberikan informasi atas pembelian saham kembali. Perusahaan menginformasikan pembelian kembali saham melalui website resmi BEI yang mencakup keputusan perusahaan untuk melakukan buyback, jumlah saham yang akan dibeli, dan jangka waktu pembelian kembali saham tersebut. Selama 10 setelah peristiwa terjadi, terdapat 42 perusahaan dari total 58 perusahaan yang telah menyampaikan keterbukaan informasi terkait pembelian saham kembali. Dengan demikian, data pergerakan rata-rata abnormal return pada periode peristiwa hanya mewakili sebagian besar dari perusahaan yang melakukan buyback pada periode 9 Maret 2020 - 29 September 2020.

Pengambilan keputusan investor juga dipengaruhi oleh sifat investor. Para investor di Indonesia kurang menganggap suatu kebijakan penting dalam pengambilan keputusan investasi. Sifat investor ini merupakan cerminan dari masyarakat Indonesia. Sebagian besar penduduk Indonesia cenderung kurang peduli terhadap kebijakan baik politik, kesehatan, maupun ekonomi. Watak masyarakat Indonesia cenderung menyepelekan kebijakan atau peristiwa dan hanya melihat atau berpikir dalam jangka pendek. Begitu pula pada peristiwa kebijakan OJK buyback saham tanpa persetujuan RUPS, investor Indonesia kurang peduli sehingga pergerakan abnormal return kurang terlihat pada periode peristiwa ini. Berdasarkan paparan tersebut, dapat disimpulkan bahwa watak masyarakat Indonesia termasuk investor yang kurang peduli, cenderung menyepelekan dan hanya berpikir jangka pendek merupakan salah satu alasan hipotesis ditolak. Selain itu, variabel yang digunakan dalam penelitian ini terbatas pada abnormal return yang mencerminkan reaksi pasar modal.

\section{SIMPULAN}

Hasil penelitian menunjukkan bahwa tidak terdapat perbedaan secara signifikan terkait abnormal pada saat sebelum dan sesudah peristiwa penerbitan kebijakan OJK tentang buyback saham tanpa persetujuan RUPS. Meskipun tidak signifikan, pasar merespon informasi tersebut yang tampak dengan adanya perbedaan rata-rata abnormal return. Keberlakuan teori efisiensi pasar menurut Beaver (1998) dalam Lako (2008) yang menjadi dasar penelitian ini tidak terbukti, terlihat dari tidak adanya hubungan antara informasi penerbitan kebijakan OJK dengan harga saham di pasar modal. Penelitian ini memiliki keterbatasan dimana konfirmasi tidak dilakukan terkait pemahaman investor terhadap peristiwa penerbitan kebijakan OJK buyback saham tanpa persetujuan RUPS. Asumsi yang digunakan dalam penelitian ini adalah bahwa reaksi pasar terjadi karena investor sadar 
atas informasi tersebut dan memahami peristiwa tersebut. Dengan demikian, penelitian selanjutnya dapat menerapkan metode penelitian tambahan seperti wawancara atau kuesioner untuk mengetahui seberapa jauh pemahaman investor mengenai peristiwa penerbitan kebijakan OJK buyback saham tanpa persetujuan RUPS.

\section{DAFTAR RUJUKAN}

Gupta, J. \& Wagner, F. (2018). The Announcement Effect of Open-Market Share Buybacks: The Case for European Firms. International Journal of Economics and Finance, 198), 117-140. doi:10.5539/ ijef.v10n8p117.

Hartono, J., Naufa, A. M., Sugiyanto, C., Arifa, C., Junarsin, E., Nahartyo, E., Wibisono, G., ..., Ali, S. (2019). Kajian Literatur dan Arah Topik Riset ke Depan. Yogyakarta: Andi.

Hidayat, T. \& Istiadah, N. (2011). Panduan Lengkap Menguasai SPSS 19 untuk Mengolah Data Statistik Penelitian. Jakarta: Media Kita.

Isa, M., Ghani, Z., \& Lee, S. P. (2011). Market Reaction to Actual Share Repurchase in Malaysia. Asian Journal of Business and Accounting, 4(2), 27-46.

Jin, H. J. \& Kim, J. C. (2018). Effects of the "Gangnam Style Syndrome" on the South Korean Stock Market. Journal of Cultural Economics, 42(1), 139-161. doi:10.1007/s10824-017-9291-3.

Khanthavit, A. (2020). World and National Stock Market Reactions to Covid-19. ABACJournal, 40(2), $1-20$.

Lako, A. (2008). Pemaduan Teori Modal Efisiensi Pasar dan Teori Relevansi Nilai untuk Mengukur Relevansi Nilai InformasiLaporan Keuangan untuk PasarSaham. doi:10.13140/RG.2.2.22564.53126.

Niu, J. (2015). Stock Price Reaction to Share Repurchase Announcements by Banks in Normal and Crisis Times. Journal of Economic \& Financial Studies, 3(2), 55-62. doi:10.18533/jefs.v3i02.156.

Pirgaip, B. (2021). Pan(dem)ic Reactions in Turkish Stock Market: Evidence from Share Repurchases. Eurasian Economic Review, 11, 381-402. doi:10.1007/s40822-021-00173-6.

Pradhan, S. K. \& Kasilingam, R. (2018). Buyback Announcement and Its Impact on Shareholders' Wealth: A Study on Bombay Stock Exchange. Asia-Pacific Journal of Management Research and Innovation, 14(3-4), 111-119. doi:10.1177/2319510x18819652.

Putra, I. M. D. H. \& Putri, I. G. A. M. A. D. (2018). Analisis Reaksi Pasar Sebelum dan Sesudah Pengumuman Kemenangan Donald Trump Menjadi Presiden Amerika Serikat. E-Jurnal Akuntansi Universitas Udayana, 23(1), 406-435. doi:10.24843/eja.2018.v23.i01.p16.

Rante, T., Falah, S., \& Pangayow, B. J. C. (2019). Reaksi Pasar Modal terhadap Pengumuman Paket Kebijakan Ekonomi XVI (Studi Empiris pada Saham Perusahaan yang Masuk dalam Indeks LQ 45). Jurnal Akuntansi \& Keuangan Daerah, 14(2), 112-123. doi: 10.52062/jakd.v14i2.1458.

Sanjiwani, P. D. A. \& Jati, I. K. (2017). Reaksi Pasar Modal terhadap Kebijakan Tax Amnesty pada saat Pengumuman dan Akhir Periode I. EJurnal Akuntansi Universitas Udayana, 19(1), 799-826.

Saragih, A. E. (2015). Pengaruh Pengumuman Pembelian Kembali Saham (Buyback) terhadap Abnormal Return dan Volume Perdagangan Saham pada Perusahaan yang Terdaftar di Bursa Efek Indonesia. Jurnal Riset Akuntansi dan Keuangan, 1(2), 115-138. doi:10.1234/akuntansi. v1i2.163.

Saraswati, N. M. A. W. \& Mustanda, I. K. (2018). Reaksi Pasar Modal Indonesia terhadap Peristiwa Pengumuman Hasil Penghitungan Suara Pemilihan Umum dan Pelantikan Presiden Amerika Serikat. EJurnal Manajemen Universitas Udayana, 76), 2971-2998. doi:10.24843/EJMUNUD.2018. v7.i06.p5.

Satryo, A. A. \& Wijayanto, A. (2019). Capital Market Reaction of Trade Wars (Event Study on the South Korean and Indonesia Stock Exchanges). Management Analysis Journal, 8(2), 253-264. doi:10.15294/maj.v9i3.33476.

Singh, B., Dhall, R., Narang, S., \& Rawat, S. (2020). The Outbreak of Covid-19 and Stock Market Responses: An Event Study and Panel Data Analysis for G-20 Countries. Global Business Review, 1-26. doi:10.1177/0972150920957274. 
Sivashanmugam, C. \& Sowmya, S. (2019). Market Reaction to Buyback Announcement: Evidences from Select Indian Manufacturing Companies.International Journal of Recent Technology and Engineering, 8(4), 9342-9353. doi:10.35940/ijrte.d9538.118419.

Smith, L. A. (2016). Share Repurchases in South Korea - Stock Price Performance Around Buyback Announcements (Thesis, Utrecht University, Utrecht). http://dspace.library.uu.nl/ handle/1874/325618.

Suganda, T. (2018). Event Study: Teori dan Pembahasan Reaksi Pasar Modal Indonesia. Malang: Seribu Bintang.

Wibowo, A. (2017). Reaksi Investor Pasar Modal Indonesia terhadap Paket Kebijakan Ekonomi Tahap IJokowi - JK (Studi pada Saham LQ 45 Periode Agustus 2015 - Pebruari 2016). Media Ekonomi dan Manajemen, 32(1), 58-70. doi:10.24856/mem.v32i1.452.

Wibowo, M. S. \& Sukmaningrum, P. S. (2020). Stock Market Reaction to the Tax Amnesty Announcement. Indonesian Capital Market Review, 11(2), 108-118. doi:10.21002/icmr. v11i2.11608.

Yulita, I. K. (2017). Reaksi Pasar Modal terhadap Pengumuman Keputusan Investasi Raja Salman di Indonesia. Jurnal Penelitian, 21(1), 95-106.

Zhang, Y., Song, W., Shen, D., \& Zhang, W. (2016). Market Reaction to Internet News: Information Diffusion and Price Pressure. Economic Modelling, 56,43-49. doi:10.1016/j.econmod.2016.03.020. 
